\title{
Characterization of Ouémé River Quality in Upper Delta Using Water Evaluation Indices and Multivariate Analysis
}

\section{Lawani Rebecca Annick Nireti, (MSc), PhD Student}

University of Abomey-Calavi, National Institute of Water, Laboratory of Applied Hydrology, Benin

Kelome Nelly Carine, Associate Prof., PhD

University of Abomey-Calavi, Laboratory of Geology, Mines and Environment (LABOGME), Benin Agassounon Djikpo Tchibozo Micheline, Associate Prof., PhD University of Abomey-Calavi, Laboratory of Standards, Microbiological,

Nutritional and Pharmacological Quality Control (LNCQMNP), Benin

doi: 10.19044/esj.2017.v13n17p170 URL:http://dx.doi.org/10.19044/esj.2017.v13n17p170

\section{Abstract}

Pollution represents a serious problem for the environment. The aim of this research was to assess the level of organic pollution of the Ouémé River and his physical quality. Nine physical and chemical parameters were measured in nine different stations between March and October 2016, during dry and rainy season. The methods used were those recommended by the French Association of Normalization (AFNOR). Data were subjected to descriptive statistical analysis and multivariate statistical technics, including principal component analysis (PCA) and variance analysis. The Leclercq Organic pollution index was used to assess the level of organic pollution. The values of the measured parameters suggest an organic pollution on all stations. The pollution degree varies according to the study area with contents that sometimes pass those recommended by the WHO standards. More advanced information about water quality for this study area were obtained. Therefore, this study will help stakeholders to better manage Ouémé River’s water.

Keywords: Water quality, pollution, spatial-temporal variation, Ouémé River

\section{Introduction}

Surface water quality is one of the major concern, affecting human health and ecological systems. In fact, rivers and their tributaries passing 
through cities receive a multitude of contaminants released from domestic and agricultural effluents (Qadir et al., 2008). Anthropogenic influences such as urbanization, industrial and agricultural practices, chemical spill accidents, dam construction, and natural processes like erosion and climatic conditions, could each affect surface water quality. Especially rivers play a major role in assimilation and transport of municipal and industrial wastewater and runoff from agricultural land (Singh et al., 2004). Therefore, the effective, long-term management of rivers requires a fundamental understanding of the hydro-morphological, chemical and biological characteristics. The excess of dissolved phosphate, Biological Oxygen Demand, Chemical Oxygen Demand and dissolved nitrogen in freshwaters, resulting from the increasing volume of urban-industrial and agricultural effluents is, of great concern.

In Benin, it is important to study the water quality of the Ouémé River in the upper Delta because many activities are carried out there, causing anthropogenic stress to the environment. Intensive farming, fishing, sand extraction, domestic effluent discharges, construction of roads and dams are among the main disruptions affecting water quality and stream morphology of this River. These can result in eutrophication and changes in stand dynamics (Aguilar-Ibarra, 2004, Chikou, 2006). A diagnosis of the current pollution situation and a rigorous follow-up of its evolution are of great importance for the conservation of this ecosystem. In the present study, data obtained are subject to index evaluation and statistical techniques to extract information about the similarities or dissimilarities between sampling sites, and to identify water quality variables responsible for spatial and temporal variations in river water quality.

\section{Materials and methods}

\section{Description of study area}

Ouémé River is the largest River of Benin Republic. It is located between $6^{\circ} 30^{\circ}$ and $10^{\circ}$ north latitude and $0^{\circ} 52$ 'and $3^{\circ} 05^{\prime}$ east longitude. Its main course is about $510 \mathrm{~km}$ long. It takes its source in the Tanéka Mountains in the Department of Atacora and receives two main tributaries, Okpara (200 km) and Zou (150 km) (Lalèyè et al., 2004). It crosses several agro-ecological zones and feeds downstream, the lagoon system ''Lake Nokoué-lagoon of Porto-Novo"' through a Delta zone. The Lower Delta of Ouémé, part of our study is located between latitude $6^{\circ} 33^{\prime} \mathrm{N}$ and $8^{\circ} 15$ and the meridians $1^{\circ} 50^{\prime}$ and $2^{\circ} 00$ 'E (Zinsou et al., 2016). The Lower Delta of Ouémé begins after municipality of Adjohoun in the department of Ouémé and ends at the south facade where the river flows into the lagoon complex 'Nokoué-Porto-Novo', (Lalèyè et al., 2004). The study area is influenced by the subequatorial climate type, characterized by two rainy seasons and two 
dry seasons. On the other hand, its hydrological regime depends on the Sudanian climate (north-Benin) with a low water period, usually lasts seven months (November to June) and a flood period (July to October) (Lalèyè, 1995). The plant formations along the area are characterized by swamps inhabited by floating plants dominated by water hyacinth (Eichornia crassipes), water lily (Nimphea lotus), water lettuce (Pistia stratiotes) and Lemna (Lemna pairciostata). There are also undeveloped marshy forests, dominated by the raffia palm (Raphia hookeri) and the oil palm (Elaeis guineensis). The part of the valley covered by the water is very productive in fish (Zinsou et al., 2016).

\section{Water Sampling}

Nine stations $\left(S_{1}\right.$ to $\left.S_{9}\right)$ were selected along the Ouémé River because they are accessible and reflect the actual characteristics of the water (Akpadanou $\left(\mathrm{S}_{1}\right)$; Affame $\left(\mathrm{S}_{2}\right)$; Atchonsa $\left(\mathrm{S}_{3}\right)$; Bonou $\left(\mathrm{S}_{4}\right)$; Houedja $\left(\mathrm{S}_{5}\right)$; Akassa $\left(\mathrm{S}_{6}\right)$; Vodounhoué $\left(\mathrm{S}_{7}\right)$; Ahlan $\left(\mathrm{S}_{8}\right)$; Dolivi $\left(\mathrm{S}_{9}\right)$. Agricultural and domestic activities identified in the study area were recorded. The locations of water samples were recorded using Garmin GPS in the study area (Figure 1). Water samples were taken during the dry period (March 2016) and during the wet season (October 2016) in three points of each study site. This last period shows intense rainfall and a violent flood. Water samples were collected in $1 \mathrm{~L}$ polyethylene bottles previously rinsed with the water of the station. Water samples were taken at least $2 \mathrm{~m}$ from the banks. Samples collected were stored in a cooler and transported to the laboratory immediately for analysis.

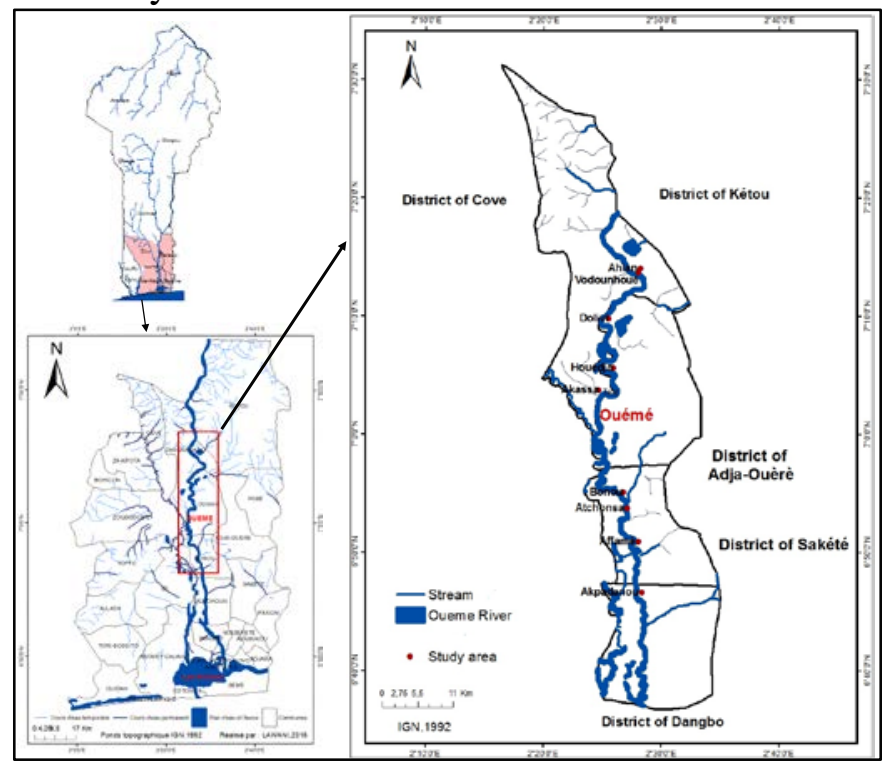

Figure 1: Map of study site and sampling area 


\section{Data processing}

For each sample, water temperature, electrical conductivity, $\mathrm{pH}$, and total dissolved solids (TDS) were measured in the field using a Multiparameter WTW 340i. Ammonium, total phosphorus ions and total nitrogen $\left(\mathrm{NO}_{2}^{-}\right)$were assessed by spectrophotometry methods in the Applied Hydrology Laboratory. The analytical methods used were those recommended by standards NF EN 26777 (1993) and NF T 90-015-2 (2000). Chemical oxygen demand (COD) was measured according to AFNOR standard NFT90-101 (2001) by colorimetric methods. 5-day biochemical oxygen demand $\left(\mathrm{BOD}_{5}\right)$ was measured by the OxiTop method in a BOD meter at $20{ }^{\circ} \mathrm{C}$ for five days, according to the AFNOR standard NF EN 1899-2, (1998). The data quality was checked by careful standardization, procedural blank measurements, spiked and duplicate samples.

Measured parameters were subjected to univariate descriptive statistical analysis (mean, standard deviation, minimum and maximum) and multivariate statistical methods that are commonly used in environmental studies (Yongming et al., 2006; Rahman et al., 2014). A principal component analysis (PCA) and analysis of variance was applied to all parameters. This method is widely used to interpret hydrochemical data (El Blidi et al., 2006, El Morhit et al., 2008). Analysis of PCA was performed in the Minitab 9.0 software on a data matrix consisting of 9 stations per campaign.

\section{Evaluation of Ouémé River water quality using indices}

The assessment of organic pollution was made using the Organic Pollution Index (OPI) (Leclercq and Vandevenne, 1987) (Table 1). The OPI depends on contents of water in ions ammonium, total nitrogen, total phosphorus and the $\mathrm{BDO}_{5}$. OPI definite 5 classes of contents for each of these parameters. The OPI is the average of the numbers of the classes of every parameter. The values of the OPI allow to distribute the organic pollutions of water in five (5) levels.

Table 1: Class Limits of the Organic Pollution Index (Leclercq, 2001)

\begin{tabular}{|c|c|c|c|c|}
\hline Classes & $\mathrm{BDO}_{5}\left(\mathrm{mgO}_{2} / \mathrm{l}\right)$ & $\mathrm{NH}_{4}(\mathrm{mg} / \mathrm{l})$ & $\mathrm{NO}_{2}^{-}(\mu \mathrm{g} / \mathrm{l})$ & $\mathrm{PO}^{3-}(\mu \mathrm{g} / \mathrm{l})$ \\
\hline 5 & $<2$ & $<0.1$ & $<5$ & $<15$ \\
\hline 4 & $2-5$ & $0.1-0.9$ & $6-10$ & $16-75$ \\
\hline 3 & $5.1-10$ & $1-2.4$ & $11-50$ & $76-250$ \\
\hline 2 & $10.1-15$ & $2.5-6$ & $51-150$ & $251-900$ \\
\hline 1 & $>15$ & $>6$ & $>150$ & $>900$ \\
\hline
\end{tabular}


Table 2: The Level of organic pollution of waters, according to the Organic Pollution indication

\begin{tabular}{|c|c|}
\hline OPI & Level of organic pollution \\
\hline 5.0 to 4.6 & Very weak organic pollution (hopeless) \\
\hline 4.5 to 4.0 & Weak organic pollution. \\
\hline 3.9 to 3.0 & Organic pollution curbed \\
\hline 2.9 to 2.0 & Strong organic pollution. \\
\hline 1.9 to 1.0 & Very strong organic pollution. \\
\hline
\end{tabular}

The classification of the organic parameters is made according to five classes of quality corresponding to the generally admitted colors (Adnour, 2001). It allows the establishment of a card of organic pollution. Measured parameters were also evaluated according to WHO (WHO, 2017) standards for drinking-water quality.

\section{Results}

\section{Physical parameters and biomass}

The recorded values of temperature in Ouémé River was ranged from $28.3^{\circ} \mathrm{C}$ (station $\mathrm{S}_{1}$ ) to $29.57^{\circ} \mathrm{C}\left(\mathrm{S}_{5}\right.$ stations) during wet periods. During the dry periods, the temperature was between $28.5^{\circ} \mathrm{C}$ (station $\mathrm{S}_{8}$ ) and $35.13^{\circ} \mathrm{C}$ (station $\mathrm{S}_{5}$ ). Temperatures were higher during low water periods (dry season). $\mathrm{pH}$ values varied around 4.99 and 6.38 along investigated sites during periods of high level of water. These $\mathrm{pH}$ was significantly higher in the low-water period (6.17 and 7.04) with an average value of 6.61. Values of conductivity showed significant variations. They fluctuated between $110 \mu \mathrm{s} / \mathrm{cm}$ in station $\mathrm{S}_{9}$ and $183.33 \mu \mathrm{s} / \mathrm{cm}$ in stations $\mathrm{S}_{3}$ and $\mathrm{S}_{4}$ during dry periods and between 80 and $93.33 \mu \mathrm{s} / \mathrm{cm}$ during wet periods. The table 3 showed mean values of $41.7 \mathrm{mg} / \mathrm{L}$ in high water for total dissolved solids. They had a higher average value in the low water period (79.02 $\pm 5.13 \mathrm{mg}$ $/ \mathrm{L})$. The salinity was zero percent (0\%) on all sampled stations during both seasons. Values of organic pollution expressed in $\mathrm{BOD}_{5}$ showed insignificant variations between the different sampling campaigns. $\mathrm{BOD}_{5}$ values ranged from 5.33mg /L to $54 \mathrm{mg} / \mathrm{L}$ with an average of $17.41 \pm 4.99 \mathrm{mg} / \mathrm{L}$ in the dry season and between $13.67 \mathrm{mg} / \mathrm{L}$ and $31 \mathrm{mg} / \mathrm{L}$ in the rainy season (Table 3 ). COD values showed a significant variation throughout the study period. They ranged from $11.83 \mathrm{mg} / \mathrm{L}$ to $110.11 \mathrm{mg} / \mathrm{L}$ with an average of $41.56 \mathrm{mg}$ $/ \mathrm{L}$ in the dry season, while in the rainy season COD values fluctuated between 29.95 and $110.53 \mathrm{mg} / \mathrm{L}$. The concentration of ammonium showed a spatial and temporal variation. Values ranged from 0.06 to $0.26 \mathrm{mg} / \mathrm{L}$ during high water periods (October). In the dry season, values fluctuated between 0.08 and $0.22 \mathrm{mg} / \mathrm{L}$ with an average of $0.16 \mathrm{mg} / \mathrm{L}$. Nitrites concentrations were low in both high and low water. 
Table 3: Range, mean and standard deviation of water quality parameters at sampling locations in the Ouémé River during dry and rainy season

\begin{tabular}{|c|c|c|c|c|c|c|c|c|c|}
\hline \multicolumn{10}{|c|}{ (2016) } \\
\hline Localités & $\mathrm{T}$ & $\mathrm{pH}$ & EC & TDS & $\mathrm{NH}_{3}$ & $\mathrm{NO}_{2}^{-}$ & COD & $\mathrm{BDO}_{5}$ & T Phosphorus \\
\hline \multirow[b]{2}{*}{ Affamè } & $29.48 \pm 0.65$ & $5.77 \pm 0.78$ & $130 \pm 43.3$ & $68.33 \pm 21.66$ & $0.14 \pm 0.025$ & $0.015 \pm 0.01$ & $64.97 \pm 40.4$ & $19.66 \pm 10.66$ & $3.76 \pm 2.0$ \\
\hline & $28.83-30.13$ & $4.99-6.56$ & $86.67-173.33$ & $46.6-90$ & $0.11-0.16$ & $0.003-0.028$ & $24.57-105.37$ & $9-30.33$ & $1.75-5.76$ \\
\hline \multirow[b]{2}{*}{ Ahlan } & $28.46 \pm 0.06$ & $6.07 \pm 6.07$ & $113.75 \pm 29.58$ & $60.66 \pm 12.66$ & $0.235 \pm 0.01$ & $0.0035 \pm 0.00$ & $56.76 \pm 16.72$ & $18.16 \pm 3.83$ & $8.02 \pm 5.28$ \\
\hline & $28.40-28.53$ & $5.80-6.97$ & $84.17-143.33$ & $48-73.33$ & $0.21-0.24$ & $0.0033-0.004$ & $40.04-73.48$ & $14.33-22$ & $2.74-13.30$ \\
\hline \multirow[b]{2}{*}{ Akassa } & $31 \pm 1.77$ & $5.955 \pm 0.86$ & $120 \pm 36.67$ & $60 \pm 16.67$ & $0.12 \pm 0.45$ & $0.0055 \pm 0.001$ & $26.35 \pm 3.6$ & $11.5 \pm 2.17$ & $4.46 \pm 0.66$ \\
\hline & $29.23-32.76$ & $5.09-6.82$ & $83.33-156.66$ & $43.340-76.6$ & $0.07-0.156$ & 0.0043- & $22.75-29.95$ & $9.33-13.67$ & 5.13 \\
\hline \multirow[b]{2}{*}{ Akpadan } & $29.36 \pm 1.06$ & $6.08 \pm 0.95$ & $131.66 \pm 38.33$ & $65 \pm 21.67$ & $0.11 \pm 0.05$ & $0.002 \pm 0.00$ & $73.46 \pm 37.06$ & $22.5 \pm 6.83$ & $4.96 \pm 0.37$ \\
\hline & $28.30-30.43$ & $5.13-7.04$ & $93.33-170$ & $43.3-86.66$ & $0.06-0.15$ & 0.002 & $36.4-110.53$ & $15.66-29.33$ & $4.58-5.33$ \\
\hline \multirow[b]{2}{*}{ Atchonsa } & $30.35 \pm 1.98$ & $6.11 \pm 0.86$ & & & $0.12 \pm 0.02$ & & & & \\
\hline & $28.37-32.33$ & $5.24-6.97$ & $86.67-183.3$ & $40-90$ & $0.10-0.143$ & 0.0027 & 66.11 & $19.67-54$ & 5.11 \\
\hline \multirow[b]{2}{*}{ Bonou } & $30.65 \pm 2.52$ & $6.08 \pm 0.71$ & $131.66 \pm 51.66$ & $63.5 \pm 23.5$ & $0.09 \pm 0.01$ & $0.0035 \pm 0.00$ & 46.35 & $20.84 \pm 0.83$ & \pm 1.76 \\
\hline & $28.13-33.16$ & $5.37-6.80$ & $80-183.3$ & $40-87$ & $0.08-0.10$ & $0.0033-0.004$ & $37.19-55.51$ & $20-21.67$ & $4.29-7.81$ \\
\hline \multirow[b]{2}{*}{ Dolivi } & $31.015 \pm 2.11$ & $6.17 \pm 0.00$ & $96.66 \pm 13.33$ & $40.41 \pm 0.40$ & $0.22 \pm 0.00$ & $0.0155 \pm 0.01$ & $21.41 \pm 9.58$ & $10.66 \pm 5.33$ & $4.47 \pm 1.04$ \\
\hline & $28.9-33.11$ & 6.17 & $83.33-110$ & $40-40.81$ & $0.22-0.223$ & $0.01-0.026$ & 11.83- 30.99 & $5.33-16$ & $3.43-5.51$ \\
\hline \multirow[b]{2}{*}{ Houedja } & $32.35 \pm 2.78$ & $6.115 \pm 0.50$ & $123.33 \pm 43.33$ & $61.66 \pm 21.66$ & $0.16 \pm 0.03$ & $0.003 \pm 0.00$ & $69.8 \pm 9.74$ & $24.66 \pm 3.33$ & $4.42 \pm 0.46$ \\
\hline & $29.57-35.13$ & $5.61-6.61$ & $80-166.63$ & $40-83.33$ & $0.12-0.193$ & $0.003-0.00$ & $60.06-79.54$ & $21.33-28$ & $3.96-4.88$ \\
\hline \multirow[b]{2}{*}{ Vodoun } & $29.25 \pm 1.08$ & $6.27 \pm 0.10$ & $123.33 \pm 43.33$ & $61.66 \pm 21.66$ & $0.18 \pm 0.015$ & & $42.01 \pm 29.26$ & $18.5 \pm 12.5$ & $5.72 \pm 2.46$ \\
\hline & $28.17-30.33$ & $6.17-6.38$ & $80-166.67$ & \begin{tabular}{|l|}
$40-83.33$ \\
\end{tabular} & $0.17-0.20$ & 0.003-0.06 & $12.74-71.27$ & $6-31$ & $3.25-8.18$ \\
\hline
\end{tabular}


Table 4: Mean and standard deviation of water quality parameters at each season in Ouémé River during dry and rainy season (2016)

\begin{tabular}{ccc} 
Variable & Season & Mean \pm St Deviation \\
$\mathrm{T}$ & $\mathrm{RS}$ & $28.66 \pm 0.10$ \\
& DS & $31.77 \pm 0.68$ \\
$\mathrm{Ph}$ & $\mathrm{RS}$ & $5.53 \pm 0.16$ \\
& DS & $6.61 \pm 0.10$ \\
$\mathrm{EC}$ & $\mathrm{RS}$ & $84.17 \pm 1.44$ \\
& DS & $161.48 \pm 7.65$ \\
TDS & RS & $42.37 \pm 1.05$ \\
& DS & $79.02 \pm 5.13$ \\
NNH3 & RS & $0.14 \pm 0.02$ \\
& DS & $0.16 \pm 0.01$ \\
Nitrite & RS & $0.013 \pm 0.01$ \\
COD & DS & $0.01 \pm 0.01$ \\
& RS & $67.16 \pm 9.96$ \\
BDO $_{5}$ & DS & $41.56 \pm 10.28$ \\
\multirow{2}{*}{ Total Phosphorus } & RS & $23.33 \pm 2.16$ \\
& DS & $17.41 \pm 4.99$ \\
& RS & $6.55 \pm 0.97$ \\
& DS & $3.93 \pm 0.41$
\end{tabular}

DS: dry season RS: Rainy season

\section{Multivariate Analysis}

Principal Component Analysis was performed in order to compare the compositional pattern between analyzed water samples and identify the factors influencing each one (Figure 2). The analysis of the results showed that most of the information is explained by the first two factorial axes. These two axes described the correlations between variables related to spatial structures, and explained $65.1 \%$ of the total information with $44.3 \%$ for axis 1 and $20.9 \%$ for axis 2 respectively.

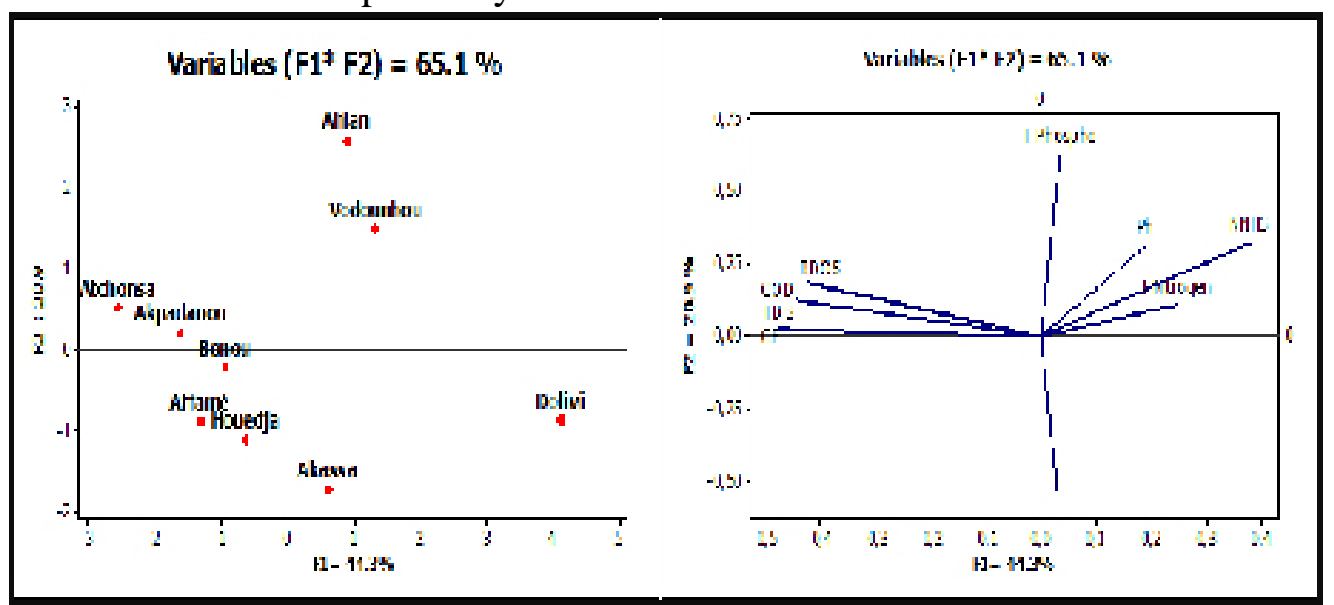

Figure 2: Principal components including all the areas studied 
Analysis of correlation of the physical-chemical parameters and their contributions to the axes showed that axis 1 expressed towards its positive pole by ammonium. Electrical conductivity (EC), TDS, COD and $\mathrm{BOD}_{5}$ are correlated to axis 1 negatively. So, stations that record high ammonium values had lower values of electrical conductivity, TDS, COD and $\mathrm{BOD}_{5}$. The $\mathrm{pH}$ and total phosphorus define positive pole of axis 2 . The projection of the different sampling points in the factorial axes showed that Dolivi locality opposes to the localities of Atchonsa and Akpadanou on axis 1 while axis 2 is correlated with localities of Vodounhoué and Ahlan. Therefore, it appears that Dolivi locality recorded high ammonium values, but low $\mathrm{pH}$ values and low water temperature. The localities of Vodounhoué and Ahlan showed high values of total phosphorus and $\mathrm{pH}$. The values of conductivity, TDS, COD and $\mathrm{BOD}_{5}$ were high in Atchonsa and Akpadanou localities. The localities of Affamè, Akassa and Houedja showed a nonsignificant variations of these parameters.

Table 5: Correlation coefficients between the variables and the main axes

$\begin{array}{cccc}\text { Variable } & \mathrm{PC}_{1} & \mathrm{PC}_{2} & \mathrm{PC}_{3} \\ \mathrm{~T} & 0.031 & -0.557 & -0.513 \\ \mathrm{Ph} & 0.19 & 0.314 & -0.553 \\ \mathrm{CE} & -0.474 & 0.024 & 0.106 \\ \mathrm{TDS} & -0.443 & 0.124 & 0.287 \\ \mathrm{NNH3} & 0.379 & 0.324 & -0.062 \\ \mathrm{Nitrite} & 0.245 & 0.108 & 0.369 \\ \mathrm{COD} & -0.423 & 0.186 & -0.197 \\ \mathrm{BOD}_{5} & -0.396 & 0.174 & -0.383 \\ \text { Phosphorus } & 0.036 & 0.628 & -0.106\end{array}$

\section{Assessment of organic pollution}

Values of Organic Pollution Index (OPI) and corresponding quality levels are given in Table 6 and Figure 3. These values ranged between 2.25 and 3.75 (strong and moderate organic pollution), $77.77 \%$ of the studied stations had a strong level of organic pollution and $33.33 \%$ had a moderate level of organic pollution.

Table 6: Organic Pollution Index (OPI) of stations

\begin{tabular}{|c|c|c|c|c|c|c|}
\hline Localities & $\mathrm{NO}_{2}^{-}(\mu \mathrm{g} / \mathrm{l})$ & $\mathrm{NH}_{4}(\mathrm{mg} / \mathrm{l})$ & $\mathrm{BDO}_{5}(\mathrm{mg} / \mathrm{L})$ & $\begin{array}{l}\mathrm{PO}^{3-}{ }_{4} \\
(\mu \mathrm{g} / \mathrm{l})\end{array}$ & OPI & Level of Organic Pollution \\
\hline$S_{1}$ & 2.00 & 0.11 & 22.50 & 4960 & 2.75 & Strong Organic Pollution \\
\hline $\mathrm{S}_{2}$ & 15.33 & 0.14 & 19.67 & 3760 & 2.25 & Strong Organic Pollution \\
\hline $\mathrm{S}_{3}$ & 3.00 & 0.12 & 36.83 & 5300 & 2.75 & Strong Organic Pollution \\
\hline $\mathrm{S}_{4}$ & 3.33 & 0.09 & 20.83 & 6006 & 3 & Moderate Organic Pollution \\
\hline $\mathrm{S}_{5}$ & 3.17 & 0.16 & 24.67 & 4420 & 2.75 & Strong Organic Pollution \\
\hline $\mathrm{S}_{6}$ & 5.83 & 0.11 & 11.50 & 4460 & 3.75 & Moderate Organic Pollution \\
\hline $\mathrm{S}_{7}$ & 3.033 & 0.19 & 18.50 & 5720 & 2.75 & Strong Organic Pollution \\
\hline $\mathrm{S}_{8}$ & 3.79 & 0.22 & 18.32 & 8020 & 2.75 & Strong Organic Pollution \\
\hline $\mathrm{S}_{9}$ & 15.50 & 0.22 & 18.16 & 4470 & 2.25 & Strong Organic Pollution \\
\hline
\end{tabular}




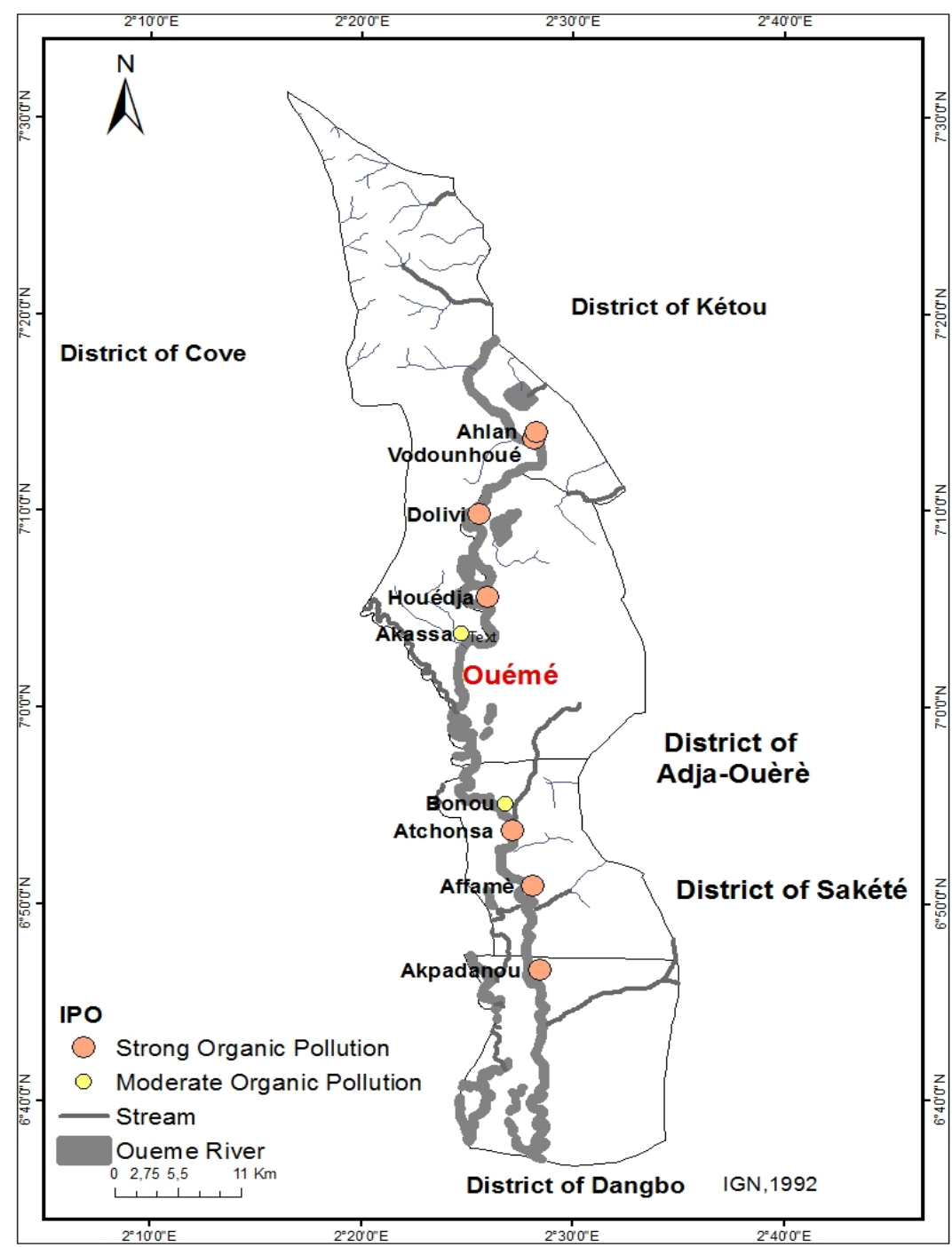

Figure 3: Organic pollution indication (OPI) map of the Ouémé River in Benin Republic

\section{Discussion}

Analytical results presented in this study indicated that Ouémé River is polluted by different pollutants. The different temperatures recorded were in line of the range tolerated by hot aquatic water $\left(25\right.$ to $\left.30^{\circ} \mathrm{C}\right)$ species with a slight variation from one station to another. $\mathrm{pH}$ values play an important role in many life processes and reflect the productivity and pollution levels of the aquatic environments. $\mathrm{pH}$ of natural water is around 6.5-8.5. $\mathrm{pH}$ is acid at all stations of Ouémé River, both during rainy and dry periods. Most of the values found were outside of the thresholds $(6.5<\mathrm{pH}$ $<9.5$ ) of the World Health Organization (WHO, 2017). These low pH values 
may be due to the presence of organic matter in the Ouémé River. The effects of different effluents of Ouémé River can also explain the results. However, according to Arrigon (1976) and Merceron (1999), these values were tolerable for most aquatic species $(5.0<\mathrm{pH}<9.0)$. These trends are corroborated by the studies of Chikou (2006) and Zinsou et al., 2016 in the same River. Similarly, low pH values were found by Keumean et al., 2013 on the Comoé River in Ivory Coast during the flood period. On the other hand, River Nile have $\mathrm{pH}$ values between 7.47 and 8.1 along investigated sites.

The recorded conductivity values showed low mineralization of the water of Ouémé River. All the samples had a conductivity below the threshold of the WHO standard which is less than $400 \mu \mathrm{s} / \mathrm{cm}$ for surface water. The temporal distribution of the electrical conductivity of the studied water samples showed a decrease during the rainy period. This decrease might be due to the dilution of water by rain during this season. Indeed, parameters such as conductivity and TDS were closely related to the nature and concentration of substances dissolved in water. TDS is used as an indicator to reflect salinity changes. Similar results were found by Akognongbé et al., (2014) at stations in the Ouémé basin at the outlet of Bétérou where the waters sampled upstream of the basin were weakly mineralized. Dianou et al., 2011 also found in its study a weak mineralization of the water of the Niger River in Niamey.

BOD represents the amount of oxygen required by living aquatic organisms in their physiological process (El-Gammal et al., 2015). BOD is the direct indication of the extent of pollution in the water body. The temporal evolution of $\mathrm{BOD}_{5}$ was characterized by higher values during the rainy season. These levels reflect the high load of organic charge, discharge in sectors which receive high amounts of agricultural and sewage wastes from different sources (Abdel Daim, 2000). Dilution caused by rainwater remains the decisive factor in this finding value. At all stations, the concentration of $\mathrm{BOD}_{5}$ was high compared to that detected in other sites such as the Ganges River in India, where it fluctuates between $2.7 \mathrm{mg} / \mathrm{L}$ and $5.95 \mathrm{mg} / \mathrm{L}$ in the Babughat station and between $0.75 \mathrm{mg} / \mathrm{L}$ and $2.8 \mathrm{mg} / \mathrm{L}$ in the Gangasar station (Sarkar et al., 2007).

The COD showed the presence of a large mineral charge with oscillating mean values. The nitrite concentration was generally low at all stations. The present findings are matching with results given by Zinsou et al., (2016) in Ouémé. In 2005, Yehouenou-Pazou found also values of nitrite concentration below $0.5 \mathrm{mg} / \mathrm{L}$ and only traces in certain study sites of Ouémé River. However, these lower values of nitrite could affect the fish health and quality because water containing nitrites can be considered suspicious or even toxic to fish at low quantity. Most of the measured 
parameters met the standards. Only the COD and $\mathrm{BOD}_{5}$ parameters indicated moderate organic pollution in all stations studied. Lake Nokoué, other surface water of Benin, show a very strong level of organic pollution (IPO = 1) (Hounsinou et al., 2011). These results are similar to those of Bahroun et kherici, (2011). They found that surface water in the region of El Tarf in Algeria, passes from strong to very strong organic pollution. In addition, the structure revealed by the principal component analysis allows to distinguish a group characterized by an organic pollution (Atchonsa, Akpadanou), a second group characterized by nitrogen pollution and a third group characterized by acid $\mathrm{pH}$ and low temperature. Domestic and agricultural activities in the surrounding area to the River Ouémé have a great impact on the organic pollution. These results allow us to conclude that water quality in Ouémé River is deteriorated in his Upper Delta parts.

\section{Conclusion}

The results of this research showed that Ouémé River is affected by two organic pollution levels. Strong organic pollution is found in the majority of study sites. This pollution was mainly caused by excess ammonium and high values of biological oxygen demand. The main physical parameters of quality showed values that are relatively compatible with aquatic life. This study highlighted the primordial influence of seasonal variations and anthropogenic activities on the water quality of the Ouémé River in the Upper Delta. This data will be completed by taking into account more exhaustive parameters (toxic heavy metals and eutrophication parameters) in future studies.

\section{References:}

1. Aguilar-Ibarra A. (2004). Les peuplements de poissons comme outil pour la gestion de la qualité environnementale du réseau hydrographique de la Garonne. Thèse de doctorat ès sciences, Institut National Polytechnique de Toulouse (France), 178pp.

2. Akognongbé A.J.S., Mama D., Vissin E. W., Michel Boko, (2014). Influence de la variabilité climatique et des activités anthropiques sur les eaux de surface dans le bassin de l’Ouémé à Bétérou au Bénin. Rev. Ivoir. Sci. Technol., 24, 278 - 298.

3. Bahroun S, Kherici B. H. (2012). Évaluation de l'indice de pollution organique dans les eaux naturelles cas de la région d'El Tarf (NordEst Algérien), Larhyss Journal (9) 171-178.

4. Chikou A, (2006). Etude de la démographie et de l'exploitation halieutique de six espèces de poissons-chats (Teleostei, Siluriformes) dans le Delta de l'Ouémé au Bénin. Thèse de Doctorat, Université de Liège, Belgique. 459 p. 
5. Dianou D, Savadogo B, Zongo D, Zougouri T, Poda J. N, Bado H, Rosillon F. (2011). Qualité des eaux de surface dans la vallée du Sourou : cas des rivières Mouhoun, Sourou, Debe et Gana au Burkina Faso. Int. J. Biol. Chem. Sci. 5(4): 1571-1589.

6. El Blidi S., Fekhaoui M., El Abidi A., Idrissi L., Benazzou T. (2006). Contamination des rizières de la plaine du Gharb (Maroc) par des métaux traces. Vecteur environnement, 46-53.

7. El Morhit M., Fekhaoui M., Serghini A., El Blidi S., El Abidi A., Bennaakam R., Yahyaoui A., Jbilou M. (2008). Impact de l'aménagement hydraulique sur la qualité des eaux et des sédiments de l'estuaire du Loukkos (côte atlantique, Maroc). Bulletin de I'Institut Scientifique, Rabat, section Sciences de la Terre, n³0, 3947.

8. Hounsinou S.P, Mama D, Sohounhloue D,Boukari M (2011).organic pollution indication as tracer for the pollution of deep boring water: the example of the township of Abomey-Calavi (Benin) Larhyss Journal, $n^{\circ} 21,217-225$.

9. Keiba Noel Keumean, Siaka Barthélémy Bamba, Gbombélé Soro, Nagnin Soro, Bernard Soro Metongo et Jean Biemi (2013). Concentration en métaux lourds des sédiments de l'estuaire du fleuve Comoé à Grand-Bassam (Sud-Est de la Côte d'Ivoire). Journal of Applied Biosciences 61, 4530-4539 .

10. Lalèyè $P$, Chikou $A$, Philippart $\mathrm{J}-\mathrm{C}$, Teugels $\mathrm{G}$, Vandewalle $\mathrm{P}$. (2004). Étude de la diversité ichtyologique du bassin du fleuve Ouémé au Bénin (Afrique de l’Ouest). Cybium 28 (4): 329-339.

11. Leclercq L et Vandevenne L, (1987). Impact d'un rejet d'eau chargée en sel et d'une pollution organique sur les peuplements de diatomées de la Gander (Grand-Duché de Luxembourg). Cahiers de Biol. Mar., 28(2), 311-318.

12. Qadir, A., Malik, R.N., Husain, S.Z., (2008). Spatio-temporal variations in water quality of Nullah Aik-tributary of the river Chenab, Pakistan. Environ. Monit. Assess. 140, 43-59.

13. Rahman, M. S., Saha, N., Molla, A. H., \& Al-Reza, S. M. (2014). Assessment of anthropogenic influence on heavy metals contamination in the aquatic ecosystem components: water, sediment, and fish. Soil and Sediment Contamination: An International Journal, 23(4), 353-373.

14. Rodier J., Bazin C., Broutin J.P., Chambon P., Champsaur H., Rodi L. 1996. L'analyse de l'eau, $8^{\text {éme }}$ édition. DUNOD (Editeur), Paris, France. 1383 p.

15. Shrestha, S. and Kazama, F. (2007). Assessment of Surface Water Quality Using Multivariate Statistical Techniques: A Case Study of 
the Fuji River Basin, Japan. Environmental Modelling and Software, 22, 464-475.

16. Uzoukwu AB, Ngoka C, Nneji N. (2004). Monitoring of seasonal variation in the water quality of Ubu River in Ekwusigo and Nnewi local government areas of Anambra State, Nigeria. Environ. Manage., 33: 886-898.

17. WHO (2017). Guidelines for drinking-water quality: Fourth edition incorporating the first addendum. 631p.

18. Yehouenou-Pazou A E, (2005). Les résidus de pesticides chimiques de synthèse dans les eaux, les sédiments et les espèces aquatiques du bassin versant du fleuve Ouémé et du lac Nokoué. Thèse de Doctorat de l’Université d'Abomey-Calavi. 216 p. Bénin.

19. Yongming, H., Peixuan, D., Junji, C., \& Posmentier, E. S. (2006). Multivariate analysis of heavy metal contamination in urban dusts of Xi'an, Central China. Science of the total environment, 355(1), 176186.

20. Zinsou H. L, Attingli A. H., Gnohossou Pierre, Adandedjan Delphine, Laleye P. (2016). Caractéristiques physico-chimiques et pollution de l'eau du Delta de l'Ouémé au Benin. Journal of Applied Biosciences. 97:9163 - 9173. 